\title{
APPENDIX VA \\ Chief ministers (patih) of Yogyakarta and Surakarta (1755-1847)
}

\author{
Yogyakarta ${ }^{1}$
}

Danureja I 13 February 1755-19 August 1799

previously Radèn Tumenggung Yudanagara (bupati of Banjarnegara in Banyumas) from the Gandakusuman family.

Danureja II 9 September 1799-28 October 1811 previously Radèn Tumenggung Mertanagara, grandson of the above. Strangled on the orders of Sultan Hamengkubuwana II in the Yogya kraton, hence known as patih séda kedhaton ('the patih who died in the kraton').

Danureja III 7 November 1811-2 December 1813 previously Kyai Tumenggung Sindunagara I, eldest son of Danureja I. Never given the title of 'Radèn Adipati' but referred to by his 'commoner' title of 'Kyai Adipati'. Acting patih 7 November 181122 January 1812, when he took the oath of allegiance to the British government. Retired as Kyai Adipati Purwa on 2 December 1813.

Danureja IV 2 December 1813-22 February 1847 previously Mas Tumenggung Sumadipura, bupati of Japan (Majakerta) in east Java, supposedly of Balinese descent from Untung Surapati. Retired to Majakerta as Pangéran Adipati Kusumayuda and died there in c. 1849.

1 Details taken from Rouffaer 1905:607 and from typed notes on the Yogyakarta patih in the Widya Budaya library of the Yogya kraton. Rouffaer's dates have been checked against the available Residency letters. 


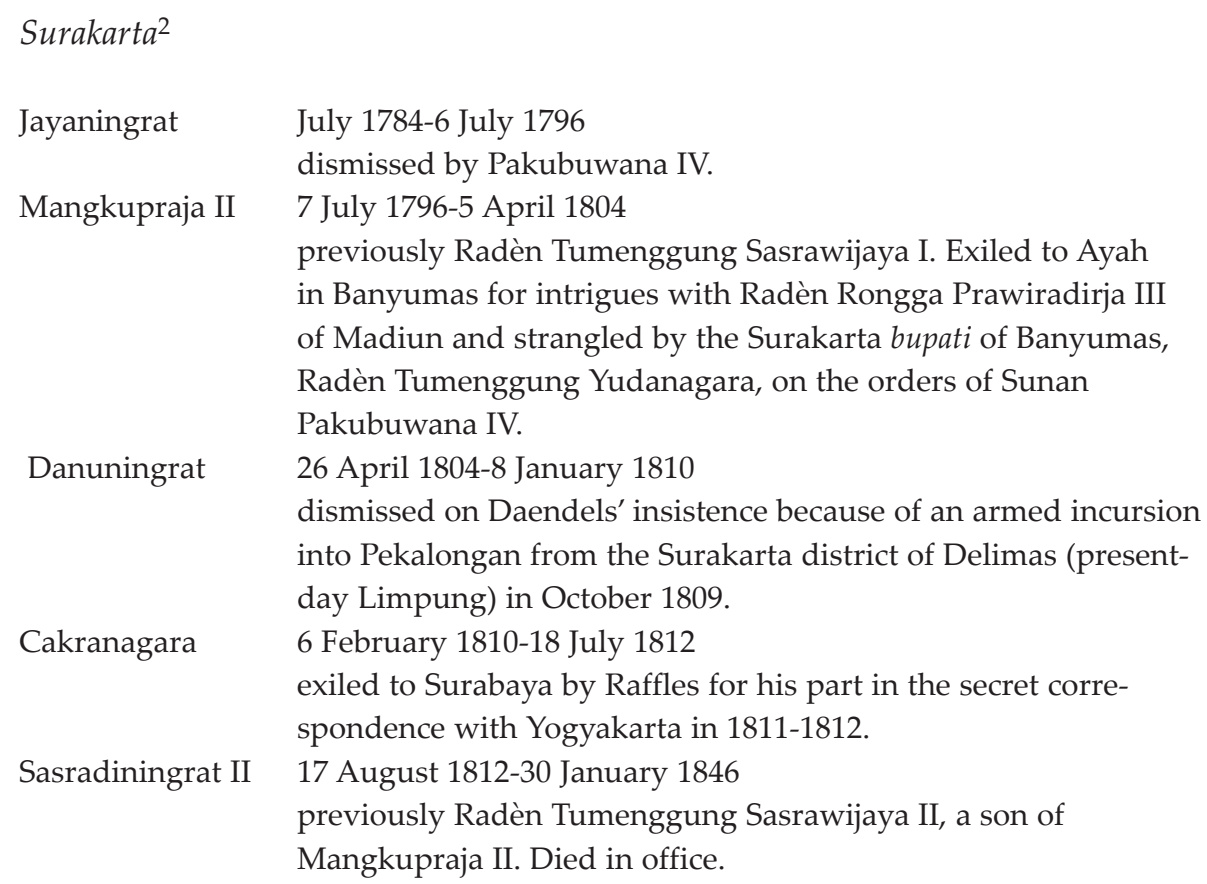

2 Details taken from Rouffaer 1905:607; Ricklefs 1974a:428. The dates have been checked in the following sources: S.Br. 53, Pakubuwana IV (Surakarta) to P.G. van Overstraten (Semarang), 10-7-1796; Van der Chijs 1895-97, XV:10-4 (decree of 8-1-1810 dismissing Danuningrat); Dj.Br. 27, H.W. Daendels (Batavia) to G.W. Wiese (Yogyakarta), 13-1-1810; Dj.Br. 37, Hamengkubuwana II (Yogyakarta) to Pakubuwana IV (Surakarta), 16 Jumadilakir AJ 1737 (19-7-1810); IOL Mack.Pr. 2, 'Chronology of Java',1816; MvK 4132, Lawick van Pabst, 'Nota', 1826. On Ayah as a place of exile for the Surakarta court, see Remmelink 1994:19. 